\title{
Cobalamin and folate binding proteins in human tumour tissue
}

\author{
K SHEPPARD, DA BRADBURY, JM DAVIES, DR RYRIE \\ From the Haematology Department, City Hospital, Nottingham NG5 1PB
}

SUMMARY The serum of an 84 year old man with disseminated carcinoma was found to contain extremely high concentrations of cobalamin and of a cobalamin binding protein with transcobalamin I characteristics. Tumour tissue samples obtained at necropsy contained considerably higher concentrations of cobalamin binding protein (R-binder) than normal tissues. Tumour tissues also contained increased concentrations of specific folate binding protein. In all tissues studied a close correlation existed between unsaturated cobalamin and unsaturated folate binding and between total cobalamin and total folate binding. These results suggest related mechanisms for the synthesis of cobalamin binding proteins of the R-binder class and folate binding proteins by tumour tissue.

Increased serum concentrations of cobalamin (vitamin B12) and of the cobalamin binding protein transcobalamin I, an R-binder, are found in at least $6 \%$ of patients with cancer. ${ }^{1}$ Hepatocellular carcinoma tissue has been found to contain 10 times as much cobalamin binding protein as normal liver tissue from the same patient, and it has therefore been suggested that tumour tissue may be the source of the high serum transcobalamin I values found in patients with cancer. ${ }^{2}$ Monitoring of serum cobalamin and cobalamin binding protein may be of particular clinical value in the initial assessment and subsequent monitoring of response to treatment in patients with variants of hepatocellular carcinoma associated with increased cobalamin binding protein synthesis. $^{3}$

In separate studies serum concentrations of specific folate binding protein have been found to be raised in some patients with cancer, ${ }^{4}$ and Corrocher et $a^{5}$ reported the presence of slightly increased amounts of folate binding protein in malignant tumours from the gastrointestinal tract compared with normal mucosa.

A high serum cobalamin concentration associated with a considerably increased level of cobalamin binding was found in an 84 year old man with widely disseminated carcinoma. The subsequent availability of tumour tissue allowed a comparative study of folate binding protein and cobalamin binding protein in tumour and normal tissues from the patient.

Accepted for publication 5 September 1984

\section{Material and methods}

Tumour tissue and adjacent normal tissue was obtained at necropsy. Histological examination of various affected organs showed involvement by anaplastic carcinoma. The site of the primary lesion could not be determined with certainty. Serum obtained before death showed that the $\alpha$-fetoprotein concentration was not raised, and hepatitis B surface antigen was not detected.

\section{SERUM STUDIES}

Serum total corrinoids (cobalamin plus its analogues capable of binding to R-binder), cobalamin, folate, and red cell folate were estimated by radioisotopic assay. ${ }^{6}$ Unsaturated cobalamin binding was determined by the coated charcoal technique of Lau et al ${ }^{7}$ using ${ }^{57}$ Co cyanocobalamin of specific activity $6 \cdot 7-$ $11 \cdot 1 \mathrm{MBq} / \mu \mathrm{g}$ (Amersham International plc). The labelled transcobalamins were separated into three components (transcobalamins I, II, and III) by chromatography on DE23 cellulose. ${ }^{8}$ Unsaturated folate binding was determined with ${ }^{125}$ I folate (Becton Dickinson UK Ltd) using extended incubation with coated charcoal to ensure specificity for folate binding protein."

TISSUE STUDIES

Tumour and histologically normal tissue samples were stored without fixation at $-30^{\circ} \mathrm{C}$ before study. Roughly $20 \mathrm{mg}$ portions of each tissue were thawed and homogenised in $5 \mathrm{ml}$ of distilled water. The sus- 
Table 1 Results of serum assays

\begin{tabular}{lcc}
\hline & $\begin{array}{l}\text { Serum value } \\
(\text { ng/l) }\end{array}$ & Normal range \\
\hline Total corrinoids & 32500 & $300-1100$ \\
Cobalamin & 25000 & $200-900$ \\
Unsaturated cobalamin binding & 26100 & $550-1500$ \\
Transcobalamin I & 22500 & $50-150$ \\
Transcobalamin II & 490 & $480-1050$ \\
Transcobalamin III & 3110 & $160-320$ \\
Unsaturated folate binding & 70 & $20-130$ \\
\hline
\end{tabular}

Transcobalamin values are expressed in terms of unsaturated cobalamin binding capacity.

pensions were centrifuged at $2500 \mathrm{~g}$ for $20 \mathrm{~min}$ and the supernatants passed through $0.8 \mu \mathrm{m}$ pore size cellulose acetate membrane filters. The total protein concentration of each solution was determined using a sensitive microtechnique. ${ }^{10}$

Total corrinoids, folate, unsaturated cobalamin binding, and unsaturated folate binding were determined on appropriate dilutions of the tissue extracts, as described for serum. Total folate binding was estimated after removal of endogenous folate by acid exposure and dextran coated charcoal separation. ${ }^{9}$ The labelled cobalamin binding proteins were chromatographed on Sephadex G-200 using 40 $\mathrm{mmol} / \mathrm{l}$ phosphate buffer, $\mathrm{pH} 7 \cdot 4$, containing 0.5 $\mathrm{mol} / \mathrm{l}$ sodium chloride, to enable the type of binding protein present to be established."

\section{Results}

The serum showed a considerably increased unsaturated cobalamin binding capacity with high corrinoid and cobalamin concentrations (Table 1). DE23 chromatogiaphy confirmed that the major increase in cobalamin binding was due to an increase in transcobalamin I. Serum and red cell folate and serum folate binding protein values were within normal limits.

Tissue studies showed that, with the exception of normal liver corrinoids, tumour tissue contained higher concentrations of corrinoids and folate than normal tissue. Tumour unsaturated cobalamin and folate binding was significantly greater than that of normal tissue (Table 2). Sephadex G-200 chromatography of tissue cobalamin binders showed a single peak in the characteristic position of R-binder in all cases except normal lung tissue, which showed R-binder plus a small transcobalamin II fraction amounting to about $5 \%$ of the binding activity present. This may have been derived from alveolar macrophages, which are capable of transcobalamin II synthesis. ${ }^{12}$ A strong correlation was found between unsaturated cobalamin binding and unsaturated folate binding protein in all the tissues studied $(\mathrm{r}=0.89, \mathrm{p}<0.001$ by paired $t$ test $)$. When total cobalamin binding, obtained by addition of unsaturated cobalamin binding to the tissue corrinoid concentration, was compared with total folate binding protein, determined using acid dissociation of endogenous folate from folate binding protein, the correlation was still apparent, though to a less significant degree $(r=0.71, p<0.05)$. The manipulations entailed in determining the total binding capacities would, however, be subject to considerably greater error than determination of unsaturated binding alone.

\section{Discussion}

The high concentrations of cobalamin binding protein in the tumour tissues studied suggest that these tissues were the source of the increased binding protein in the serum, although definitive studies of protein synthesis were not undertaken in this case. The strong correlation between cobalamin binding and folate binding protein suggests that the mechanism of production within the tissues was closely related. The possibility of a relation in the synthesis of these proteins is not unexpected. Both cobalamin binding proteins of the $\mathrm{R}$-binder class and folate binding protein have been reported to be present in breast milk,,$^{13}{ }^{14}$ plasma, ${ }^{13}{ }^{15}$ and in the secondary granules

Table 2 Cobalamin and folate binding values obtained using aqueous tissue extracts

\begin{tabular}{|c|c|c|c|c|}
\hline \multirow[t]{2}{*}{ Tissue } & \multicolumn{2}{|c|}{ Cobalamin binding $(n g / g)$} & \multicolumn{2}{|c|}{ Folate binding (ng/g) } \\
\hline & Unsaturated & Total & Unsaturated & Total \\
\hline $\begin{array}{l}\text { Normal brain } \\
\text { Brain tumour } \\
\text { Normal liver } \\
\text { Liver tumour } \\
\text { Normal heart } \\
\text { Heart tumour } \\
\text { Normal lung } \\
\text { Lung tumour } \\
\text { Duodenal tumour } \\
\text { Thyroid tumour }\end{array}$ & $\begin{array}{r}<10 \\
2136 \\
<10 \\
2120 \\
<10 \\
725 \\
403 \\
3045 \\
188 \\
52\end{array}$ & $\begin{array}{r}770 \\
2827 \\
5440 \\
2542 \\
407 \\
1146 \\
1257 \\
3296 \\
549 \\
480\end{array}$ & $\begin{array}{r}2 \cdot 7 \\
17 \cdot 9 \\
4 \cdot 1 \\
33 \cdot 3 \\
6 \cdot 6 \\
10 \cdot 1 \\
17 \cdot 6 \\
30 \cdot 6 \\
10 \cdot 6 \\
4 \cdot 2\end{array}$ & $\begin{array}{l}4 \cdot 4 \\
28 \cdot 7 \\
96 \cdot 1 \\
126 \\
20 \cdot 1 \\
50 \\
36 \cdot 5 \\
85 \\
40 \cdot 8 \\
16 \cdot 5\end{array}$ \\
\hline
\end{tabular}

Values are expressed as nanogram of binding per gram of soluble protein. 
of neutrophils. ${ }^{1617}$ We have also found folate binding protein in saliva and semen (unpublished observations), both of which contain R-binder. ${ }^{18} 19$ $\mathrm{R}$-binders and folate binding protein are similar in that both are glycoproteins showing heterogeneity on isoelectric focusing ${ }^{2021}$ and appear to have similar roles in the plasma in that cobalamin or folate carried on these proteins is apparently available only to binding sites in the liver. ${ }^{22} 23$

Although concentrations of both folate and cobalamin binding proteins were clearly increased in the tumour tissues examined, there were no detectable abnormalities of serum folate binding protein values. This discrepancy may relate to differences in effectiveness in plasma clearance of tumour derived cobalamin and folate binding proteins in this patient. It has been suggested that tumour derived transcobalamin I may have a slow clearance rate owing to increased sialation of the protein. ${ }^{2}$ The effect of sialation on the clearance of folate binding protein has not been described.

This study demonstrates that abnormalities of folate and cobalamin binding proteins may be detectable in both the serum and tumour tissue of some patients with malignant disease. Furthermore, other studies have shown that such abnormalities may not be uncommon. ${ }^{12425}$ The application of cobalamin and folate binding capacity assays to patients with suspected or proved malignancy may be of value in both diagnosis and monitoring of subsequent treatment in those patients with increased serum concentrations of these proteins.

\section{References}

' Carmel R, Eisenberg L. Serum vitamin B12 and transcobalamin abnormalities in patients with cancer. Cancer 1977;40:134853.

${ }^{2}$ Burger RL, Waxman S, Gilbert HS, Mehlman CS, Allen RH. Isolation and characterisation of a novel vitamin B12- binding protein associated with hepatocellular carcinoma. J Clin Invest 1975;56: 1262-70.

${ }^{3}$ Paradinas FJ, Melia WM, Wilkinson ML, et al. High serum vitamin B12 binding capacity as a marker of the fibrolamellar variant of hepatocellular carcinoma. $\mathrm{Br} \mathrm{Med} \mathrm{J} \mathrm{1982;}$ 285: 840-2

${ }^{4}$ Eichner ER, McDonald CR, Dickson BA. Elevated serum levels of unsaturated folate binding protein: clinical correlates in a general hospital population. Am J Clin Nutr 1978;31:198892.

${ }^{5}$ Corrocher R, De Sandre G, Ambrosetti A, Pachor ML, Bambara LM, Hoffbrand AV. Specific and non-specific folate binding protein in normal and malignant human tissues. J Clin Pathol 1978;31:659-65.

- Sheppard K, Ryrie D. Changes in serum levels of cobalamin and cobalamin analogues in folate deficiency. Scand J Haematol 1980; 25:401-6.
' Gottlieb C, Lau.K-S, Wasserman LR, Herbert V. Rapid charcoa assay for intrinsic factor (IF), gastric juice unsaturated B12 binding capacity, antibody to IF, and serum unsaturated B12 binding capacity. Blood 1965;25:875-84.

${ }^{8}$ Zittoun J, Zittoun R, Marquet J, Sultan C. The three transcobalamins in myeloproliferative disorders and acute leukaemia. Br J Haematol 1975;31:287-98.

${ }^{9}$ Bradbury D, Sheppard K, Davies J. Specific folate-binding proteins present in some commercial serum albumin preparations. Med Lab Sci 1983;40:187-8.

${ }^{10}$ Ohnishi ST, Barr JK. A simplified method of quantitating protein using the biuret and phenol reagents. Anal Biochem 1978;86: 193-200.

"Bloomfield FJ, Scott JM. Identification of a new vitamin B12 binder (transcobalamin III) in normal human serum. Br J Haematol 1972;22:33-42.

${ }^{12}$ Rachmilewitz B, Rachmilewitz M, Chaouat M, Schlesinger M. The synthesis of transcobalamin II a vitamin B12 transport protein by stimulated mouse peritoneal macrophages. Biomedicine 1977;27:213-4.

${ }^{13}$ Stenman U-H. Characterisation of R-type vitamin B12-binding proteins by isoelectric focussing. II. Comparison of cobalophilin (R-binders) from different sources. Scand J Clin Lab Invest 1975; 35: 147-55.

${ }^{14}$ Waxman S, Schreiber C. Isolation and characterisation of a folate binding protein(s) (FABP) from human milk by affinity chromatography. Blood 1974;44:911.

is Waxman S, Schreiber C. Measurement of serum folate levels and serum folic acid-binding protein by ${ }^{3} \mathrm{H}-\mathrm{PGA}$ radioassay. Blood 1973;42:281-90.

${ }^{16}$ Kane SP, Peters TJ. Analytical subcellular fractionation of human granulocytes with reference to the localisation of vitamin B12-binding protein. Clin Sci Mol Med 1974;49:171-82.

${ }^{17}$ Colman N, Herbert V. Studies using the calcium ionophore A23187 suggests localization of the human granulocyte folate binder in specific (secondary) granules. Clin Res 1979; 27:291A.

${ }^{18}$ Hurliman J, Zuber C. Vitamin B12-binders in human body. fluids. I. Antigenic and physico-chemical characteristics. Clin Exp Immunol 1969;4: 125-40.

${ }^{19}$ Finkler AE, Green PD, Hall CA. Immunological properties of human vitamin $\mathrm{B} 12$ binders. Biochim Biophys Acta 1970;200:151-9.

${ }^{20}$ Stenman U-H. Characterization of R-type vitamin B12-binding proteins by isoelectric focussing. I. The relationship between transcobalamin I, transcobalamin III and the granulocyte $\mathbf{R}$ protein. Scand J Haematol 1974; 13:129-34.

${ }^{21}$ Fischer CD, da Costa M, Rothenberg SP. Properties of purified folate-binding proteins from chronic myeloid leukaemia cells. Biochim Biophys Acta 1978;543:328-39.

${ }_{22}$ Burger RL, Schneider RJ, Mehlman CS, Allen RH. Human plasma R-type vitamin B12 binding proteins. J Biol Chem 1975; 250: 7707-13.

${ }^{23}$ Fernandes-Costa F, Metz J. Role of serum folate binders in the delivery of folate to tissues and to the fetus. $\mathrm{Br} \mathrm{J} \mathrm{Haematol}$ 1979; 41:335-42.

${ }^{24}$ Fukada $M$. On the clinical aspects of serum transcobalamins. Acta Haemotol Jap 1970; 33:185-6.

${ }^{25}$ Carmel R. Extreme elevation of serum transcobalamin I in patients with metastatic cancer. $N$ Engl $J$ Med 1975;292:282-4.

Requests for reprints to: Mr K Sheppard, Haematology Dept, City Hospital, Hucknall Rd, Nottingham NG5 1PB, England. 